Atmos. Chem. Phys., 13, 4801-4814, 2013

www.atmos-chem-phys.net/13/4801/2013/

doi:10.5194/acp-13-4801-2013

(c) Author(s) 2013. CC Attribution 3.0 License.

\title{
Aerosol size-resolved trace metal composition in remote northern tropical Atlantic marine environment: case study Cape Verde islands
}

\author{
K. W. Fomba, K. Müller, D. van Pinxteren, and H. Herrmann \\ TROPOS - Leibniz-Institute for Tropospheric Research, Permoserstr. 15, 04318 Leipzig, Germany \\ Correspondence to: H. Herrmann (herrmann@ tropos.de)
}

Received: 26 October 2012 - Published in Atmos. Chem. Phys. Discuss.: 16 November 2012

Revised: 5 March 2013 - Accepted: 15 March 2013 - Published: 8 May 2013

\begin{abstract}
Size-resolved trace metal concentrations of 15 elements in aerosol particles at the Cape Verde Atmospheric Observatory (CVAO) under remote background conditions were investigated through analysis of aerosol samples collected during intensive field studies from January 2007 to November 2011 using total reflection $\mathrm{x}$-ray fluorescence (TXRF). The identification of the main air mass origin that influence remote marine aerosol in the northern tropical Atlantic has been investigated. In total, 317 samples were collected. The dataset was analyzed according to the main air mass inflow at the station. We found that remote conditions make up about $45 \%$ of the meteorological conditions in a year at CVAO and thus the northern tropical Atlantic. Surprisingly, air masses from North America are often responsible for higher trace metal concentrations in this region.

Elements such as $\mathrm{Zn}, \mathrm{Pb}, \mathrm{Cu}, \mathrm{Cr}, \mathrm{Ni}$, and $\mathrm{V}$ were mostly found in the submicron size fractions, while elements with dominant crustal or oceanic origin such as $\mathrm{Fe}, \mathrm{Ti}, \mathrm{Mn}, \mathrm{Sr}$, and $\mathrm{Rb}$ were found in the coarse fractions $(>1 \mu \mathrm{m})$. The highest metal concentrations, especially for $\mathrm{Zn}\left(3.23 \mathrm{ng} \mathrm{m}^{-3}\right), \mathrm{Cu}$ $\left(0.81 \mathrm{ng} \mathrm{m}^{-3}\right), \operatorname{Sr}\left(2.63 \mathrm{ng} \mathrm{m}^{-3}\right)$, and $\mathrm{Cr}\left(0.53 \mathrm{ng} \mathrm{m}^{-3}\right)$, were observed in air masses originating from North America and the concentrations were within the same concentration range to those reported previously in the literature for remote marine aerosols. Fe $\left(12.26 \mathrm{ng} \mathrm{m}^{-3}\right)$, Ti $\left(0.91 \mathrm{ng} \mathrm{m}^{-3}\right)$, and $\mathrm{Mn}$ $\left(0.35 \mathrm{ng} \mathrm{m}^{-3}\right)$ showed higher concentrations when air mass came from Europe and the Canary Islands. $\mathrm{Pb}$ concentration was low $\left(<0.20 \mathrm{ng} \mathrm{m}^{-3}\right)$ and did not vary significantly with air mass direction. The low $\mathrm{Pb}$ concentration is indicative of the complete phase-out of leaded gasoline even in African countries. Crustal enrichment factor values decreased from
\end{abstract}

fine to coarse-mode particles with low values $(<4)$ observed for $\mathrm{Fe}, \mathrm{Mn}$, and $\mathrm{Rb}$, and high values ( $>20)$ for $\mathrm{Zn}, \mathrm{Cu}, \mathrm{Ni}$, $\mathrm{Cr}, \mathrm{Pb}$, and $\mathrm{Se}$. The observed enrichment of the elements was attributed to crustal, marine, anthropogenic, and biogenic sources, as well as long-range transport and resuspension. $\mathrm{Zn}, \mathrm{Cu}$ and $\mathrm{Pb}$ were indicators of anthropogenic activities, while $\mathrm{Ti}$ and $\mathrm{Sr}$ were indicators of crustal and marine origin, respectively. Oceanic and biogenic emissions might have contributed to most of the Se observed. This work provides the first long-term size-resolved trace metals study for remote tropical northern Atlantic marine aerosols and the dataset could serve as good initiation of yearly flux estimates.

\section{Introduction}

Atmospheric input of trace metals - for example, Fe, Mn, $\mathrm{Cu}, \mathrm{Cd}$, and $\mathrm{Zn}$ - is essential for marine productivity (Morel et al., 2003). The atmosphere has been recognized as a major source of metals to the open oceans (Duce et al., 1991) since inputs from river and land erosion are mostly localized, whereas atmospheric inputs are not localized but spread over larger area. Islands are very useful in studying deposition patterns to the open oceans since they experience similar conditions to the oceans and provide long-lasting infrastructures for carrying out long- and short-term experiments. In the tropical northern Atlantic, the Cape Verde islands are well situated for carrying out such experiments, and atmospheric conditions in this region are representative of a larger part of the northern tropical Atlantic. This was one of the principal reasons for the creation of the Cape Verde Atmospheric 
Observatory (CVAO). CVAO thus provides a platform for studying both remote marine aerosols as well as continental and Saharan-dust-dominated aerosols. Aerosol compositions being observed at CVAO are affected by mixing of air masses and the influence of aerosols from sources situated in North America, Europe or Africa. Thus, the aerosol composition varies temporally and spatially in concert with meteorological conditions.

Remote conditions at the CVAO are attributed to air masses that do not come from neighboring continental Africa since such air parcels are known to carry significant amounts of mineral aerosols, especially during Saharan dust outbreaks. The outbreaks observed at CVAO have seasonal patterns with peaks between December and March. However, dust transport to the Atlantic usually has two primary seasons, which are in winter and summer, but the transport during summer occurs at higher altitudes and is not usually observed at the CVAO. Such seasonal trends were reported by Chiapello et al. (1997, 1999, and 2005) at Sal Island - an island in Cape Verde. The other months are mostly dominated by remote conditions. During such conditions, aerosol trace metals originate from oceanic emissions as well as longrange transport from Southern Europe and North America.

Previous ship cruises and other works in this region have mostly been focused on the influence of Saharan dust outflow from the African continent (Johansen et al., 1999; Buck et al., 2010a, b; Hand et al., 2004), but not much has been done to better characterize the aerosol trace metal in remote conditions, which despite their low concentrations are also of importance to the marine biota.

Aerosol trace metal studies in some remote regions of the Atlantic Ocean at Bermuda (Huang et al., 1996; Duce et al., 1976; Spokes et al., 2001; Witt et al., 2006) or during ship cruises (Spokes et al., 2001; Witt et al., 2006) and even in Antarctica (Weller et al., 2008) have shown that trace metals concentrations in particulate matter (PM) are enriched above the oceanic and crustal sources and are found in different size fractions. Anthropogenic activities that lead to emission of trace metals are usually related to high-temperature processes such as smelting, fuel combustion or waste incineration (Pacyna et al., 2007; Galloway et al., 1982). In such processes metals are mostly emitted in gaseous forms and they rapidly condense on the surfaces of particles having a high surface area, leading to their likely presence in the finemode $(<1 \mu \mathrm{m})$ aerosol particles (Galloway et al., 1982). Recently, there have been reports on trace metals found in marine microgels and colloids (Bertine and VernonClark, 1996; Guo et al., 2000). These gels and colloids usually less than $1 \mu \mathrm{m}$ in size have been found to act as cloud condensation nuclei (Orellana et al., 2011). Thus, although they are not yet well characterized in marine aerosols, they may contribute to the trace metal budget in the submicrometer aerosol particle fraction. Metals from coarse particles $(>1 \mu \mathrm{m})$ are mostly attributed to mechanical processes such as rock weathering, soil erosion, volcanic eruptions, or bubble bursting. Coarse- mode particles are deposited faster and have atmospheric life times of up to 4 days, while fine-mode particles live longer and may attain life times of more than 6 days under dry conditions. In regions with low rain probability and thus less influence of wet deposition such as the Cape Verde islands and its local environment (Lee et al., 2010), such particles can readily reach the above atmospheric life times (Lawler et al., 2009; Johansen et al., 1999). Therefore, emissions from anthropogenic activities may have significant influence on trace metal budget in this region.

Within the present study, results of data collected during a series of nine intensive field campaigns from January 2007 to November 2011 on size-resolved trace metal composition in remote marine aerosols observed at the CVAO are presented. The aim of this work was to characterize the variability of bioactive trace metals, such as $\mathrm{Mn}, \mathrm{Fe}, \mathrm{Cu}, \mathrm{Zn}, \mathrm{Se}, \mathrm{V}, \mathrm{Cr}$, $\mathrm{Pb}$, and $\mathrm{Ni}$, and evaluate their natural background concentrations, size distribution and their source origins with the help of crustal enrichment factors and back trajectory analysis in this region of the Atlantic. Major sea salt elements such as $\mathrm{K}, \mathrm{Ca}, \mathrm{S}$, and $\mathrm{Cl}$ were not the focus of this work.

\section{Experimental}

\subsection{Site and sampling}

Aerosol sampling was performed at the CVAO, which is located northeast of the island of Sao Vicente, Cape Verde, and is situated $70 \mathrm{~m}$ from its coastline at $16^{\circ} 51^{\prime} 49 \mathrm{~N}$, $24^{\circ} 52^{\prime} 02 \mathrm{~W}$, experiencing mostly northeasterly winds. The annual average temperature at Sao Vicente is about $25^{\circ} \mathrm{C}$ and it is an arid region with a maximum of $50 \mathrm{~mm}$ of rainfall per year. Sample collection was done on top of a tower with an inlet height of $32 \mathrm{~m}$ above ground to reduce strong influence of sea spray on the collected particles. Due to the location of the station, influences from the island-like orographic influences in dust sedimentation and anthropogenic emissions are negligible. Thus, the collected samples are representative of a clean atmosphere over the ocean and not contaminated by materials from the islands. A picture of the CVAO station is shown in Fig. 1 with a clear view of its coastline location, the $30 \mathrm{~m}$ high measurement tower, measurement containers, and subsidiary electrical power infrastructure.

Particles were sampled using a $\mathrm{PM}_{10}$ high volume (HV) Digitel (DHA-80) collector on quartz filters in $72 \mathrm{~h}$ periods throughout the year for aerosol mass concentration and further chemical analysis. During intensive campaigns lasting 4-6 weeks, size-resolved sampling was carried out using a 5-stage Berner low-pressure impactor with a $\mathrm{PM}_{10}$ isokinetic inlet (Hauke, Gmunden, Austria) operated at a flow rate of $75 \mathrm{~L} \mathrm{~min}^{-1}$ in a $24 \mathrm{~h}$ period with about 45 min reserved for the replacement of the samples. The impactor samples were collected on annealed aluminum foils and polycarbonate (nuclepore) foils (Wicom, Heppenheim, Germany). The 


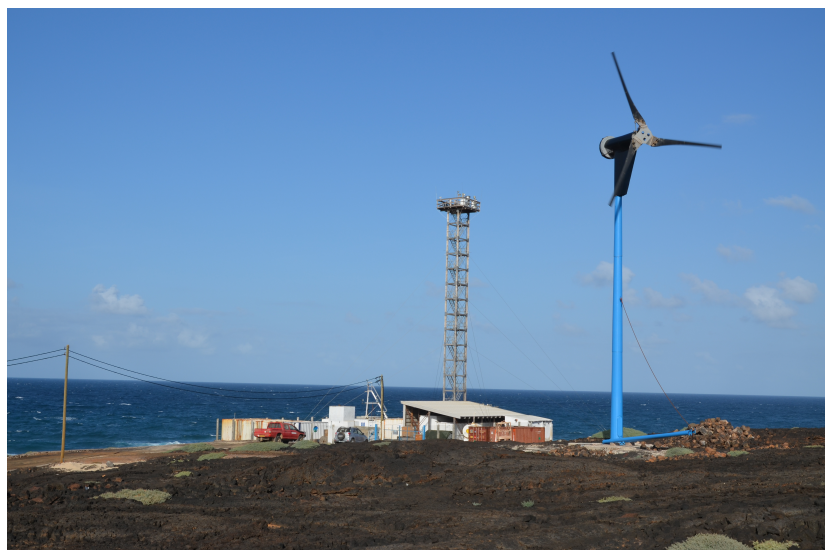

Fig. 1. CVAO station situated at the coastline of the Sao Vicente Island in the northern tropical Atlantic with clear view of the $30 \mathrm{~m}$ high measurement tower, some measurement containers, and a wind turbine for subsidizing electrical energy.

nuclepore foils were placed on the aluminum foils on each impactor stage and were used for the determination of metals. The impactor stage cutoffs were as follows: stage 1 (St._1):

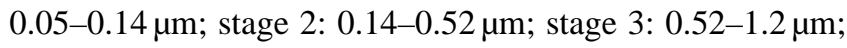
stage 4: $1.2-3.5 \mu \mathrm{m}$; stage 5 (St. 5): 3.5-10 $\mu \mathrm{m}$.

Generally, sampling with ungreased foils could lead to increased particle bounce-off inside of a cascade impactor, depending on aerosol properties and ambient relative humidity. However, due to the proximity of the CVAO to the shores, the relative humidity did not vary significantly throughout the year, rendering such effects negligible. Such events could be observed only during dust storms and could account for about less than $5 \%$ particle loss depending on the dust loading.

After sampling, filters were stored in aluminum boxes at $5{ }^{\circ} \mathrm{C}$ at the station for $24-48 \mathrm{~h}$ and subsequently frozen at $-20^{\circ} \mathrm{C}$. The samples were thereafter transported under frozen conditions from Cape Verde to Leipzig (Germany). To estimate the mass of the particles, the filters were equilibrated for 3 days at $20 \pm 1{ }^{\circ} \mathrm{C}$ and $50 \pm 5 \%$ relative humidity before and after sampling and thereafter weighed. The mass of the filters were determined using a microbalance (HV filter: MettlerAT261 Delta Range; impactor foils: Mettler Toledo UMT2).

\subsection{Metal analysis}

Trace metal analysis on nuclepore foils sampled using the Berner impactor was carried out using Total Reflection X-Ray Fluorescence (TXRF) S2 PICOFOX (Bruker AXS, Berlin, Germany) equipped with a Mo-X-ray source on polished quartz substrates. During impactor sampling, spots are created on the impaction surface due to particle impaction through defined hole sizes on each impaction stage. The visible particle spots on each stage are then used for further anal- ysis. In the case of metal analysis, the nuclepore foils were cut with respect to the number of visible particle spots on the foils ( 6 spots for stage 1, 3 for stage 2, 2 for stage 3, and 1 for stages 4 and 5). Cut nuclepore foils were placed on TXRF sample holder substrates, and $5 \mu \mathrm{L}$ of $65 \%$ concentrated $\mathrm{HNO}_{3}$ was added to help dissolve bigger particles on spots and to improve the particle spot homogeneity and adhesion of the foil to the substrates surface. In addition, gallium was added as internal standard. Depending on the size fraction, different gallium concentrations were applied (10 ng for the three submicrometer fractions and $100 \mathrm{ng}$ for the coarse-mode fractions). The solution was left to evaporate at about $100^{\circ} \mathrm{C}$ and thereafter the substrates containing the particles on the foils were measured. As reported by Müller et al. (2010), the cut foil diameters were typically $6 \mathrm{~mm}$ and were close to the TXRF beam diameter of $10 \mathrm{~mm}$. However, due to sample orientation on the substrate, samples were measured at two different angles having a difference of $90^{\circ}$ between them in order to ensure a complete excitation of the particle spots. Each sample was measured 3 times at each angle and the maximum value from the measurements at the different angles was taken as the elements value on the substrate. As a measure of quality assurance and to verify that the whole sample was analyzed, a multielement standard (Lot N: N15521, C.P.A. Ltd, Bulgaria) including the elements $\mathrm{Al}, \mathrm{As}, \mathrm{B}, \mathrm{Ba}, \mathrm{Be}, \mathrm{Ca}, \mathrm{Cd}, \mathrm{Co}, \mathrm{Cr}, \mathrm{Cu}, \mathrm{Fe}, \mathrm{K}, \mathrm{Li}, \mathrm{Mg}$, $\mathrm{Mo}, \mathrm{Ni}, \mathrm{Pb}, \mathrm{Sb}, \mathrm{Se}, \mathrm{Sr}, \mathrm{Ti}, \mathrm{Tl}, \mathrm{V}$, and $\mathrm{Zn}$ was measured. The obtained results were in good agreement (with a deviation of $\pm 5 \%$ ) with the values provided by the manufacturer, thereby justifying this procedure.

PICOFOX is able to analyze elements from $\mathrm{Al}$ to Bi. However, in this work the focus has been only on the aerosol trace metals that are not naturally expected to reside in remote aerosols in high concentrations compared to major sea salt elements such as $\mathrm{Cl}, \mathrm{Br}, \mathrm{K}, \mathrm{S}$ or $\mathrm{Ca}$. The studied trace metals were $\mathrm{Mn}, \mathrm{Fe}, \mathrm{Cu}, \mathrm{Zn}, \mathrm{Se}, \mathrm{V}, \mathrm{Cr}, \mathrm{Pb}, \mathrm{Ni}, \mathrm{Ti}, \mathrm{Rb}, \mathrm{Sr}, \mathrm{Ba}$, $\mathrm{La}$, and $\mathrm{Ce}$. The other trace elements not considered in this work, such as elements from Pr to Tl, were not detected or had concentrations below the background level for elements such as $\mathrm{Y}, \mathrm{Zr}, \mathrm{Nb}, \mathrm{Ru}, \mathrm{Rh}, \mathrm{Cd}, \mathrm{Pd}, \mathrm{Ag}, \mathrm{Sn}, \mathrm{Sb}$, and Te. Due to the low crustal content in the remote marine aerosols analyzed and the high background values of $\mathrm{Si}$ and $\mathrm{Al}$ coming from the quartz substrate and aluminum foils used during the sampling, respectively, the concentrations of $\mathrm{Si}$ and $\mathrm{Al}$ could not be effectively quantified. Furthermore, the sample preparation method (e.g., the substrate heating at $100^{\circ} \mathrm{C}$ ) made quantification of volatile species such as $\mathrm{Cl}$ and $\mathrm{Br}$ difficult.

The blank values of the polycarbonate filters and the quartz substrates were measured (Table 1). The filter field blanks were higher than those of the substrate. The typical blank values of the quartz substrates $(n=75)$ of these elements were $<10 \mathrm{pg}$ except for $\mathrm{Fe}$, where values were $<20 \mathrm{pg}$. A total of 20 field blank filters were analyzed during the stipulated sampling period and were prepared using the same procedure as those of the probed filters as stated above. The field blanks 
Table 1. Average blank values of quartz substrate $(n=75)$ and filter blank $(n=20)$ and overall method detection limit (MDL). All values are given in ng. Typical sampled volume was $105 \mathrm{~m}^{3}$. n.d. implies not detected.

\begin{tabular}{lrr|rrr}
\hline & \multicolumn{2}{c}{ Substrate } & \multicolumn{2}{c}{ Filter blank } & MDL \\
\cline { 2 - 5 } Element & Mean & Std. & Mean & Std. & $3 \times$ Std. \\
\hline $\mathrm{Ti}$ & 0.008 & 0.004 & 0.043 & 0.011 & 0.033 \\
$\mathrm{~V}$ & 0.003 & 0.002 & 0.011 & 0.003 & 0.009 \\
$\mathrm{Cr}$ & 0.005 & 0.002 & 0.032 & 0.028 & 0.084 \\
$\mathrm{Mn}$ & 0.004 & 0.002 & 0.005 & 0.008 & 0.024 \\
$\mathrm{Fe}$ & 0.018 & 0.028 & 0.45 & 0.148 & 0.444 \\
$\mathrm{Ni}$ & 0.004 & 0.003 & 0.01 & 0.012 & 0.036 \\
$\mathrm{Cu}$ & 0.004 & 0.005 & 0.089 & 0.016 & 0.048 \\
$\mathrm{Zn}$ & 0.008 & 0.003 & 0.166 & 0.041 & 0.123 \\
$\mathrm{Se}$ & $\mathrm{n} . \mathrm{d}$ & & $\mathrm{n} . \mathrm{d}$ & & \\
$\mathrm{Rb}$ & 0.002 & 0.001 & 0.004 & 0.004 & 0.012 \\
$\mathrm{Sr}$ & 0.005 & 0.003 & 0.102 & 0.031 & 0.093 \\
$\mathrm{Ba}$ & 0.003 & 0.001 & 0.007 & 0.004 & 0.012 \\
$\mathrm{La}$ & 0.003 & 0.004 & 0.004 & 0.003 & 0.009 \\
$\mathrm{Ce}$ & 0.005 & 0.003 & 0.007 & 0.005 & 0.015 \\
$\mathrm{~Pb}$ & 0.006 & 0.002 & 0.02 & 0.019 & 0.057 \\
\hline
\end{tabular}

were filters that we deployed to the field and to the instrument but air was not sucked through them. Their elemental average values were used as filter blank values (Table 1). The highest blank values were observed for $\mathrm{Fe}, \mathrm{Zn}$, and $\mathrm{Sr}$, and the lowest for $\mathrm{Se}, \mathrm{La}$, and $\mathrm{Rb}$. Blank correction was done by subtracting blank filter values from those of the probed filters.

In principle, the detection limit of TXRF is in the picogram range, but also depends on the substrate background and sample type with lower limits for very thin films compared to powder samples, provided the substrate surface is well polished. The method detection limit was estimated as three times the standard deviation (Std.) of the filter blank values (Table 1). For all the analyzed elements, more than $90 \%$ of the samples had values that were above the method detection limit. However, the blank subtraction method led to uncertainties and estimation errors especially for the first impaction stage of about $\pm 25-35 \%$ due to low mass, while uncertainties of about $\pm 7-15 \%$ were obtained for the other stages, with the higher percentage in the lower stages especially for elements with higher method detection limits.

\subsection{Back trajectory analysis}

Air mass back trajectory footprints for all collected samples were performed to assist in the data interpretation. $96 \mathrm{~h}$ back trajectories were calculated for every hour within the sample collection interval using the PC version of the NOAA HYSPLIT (Hybrid Single Particle Lagrangian Integrated Trajectory) model (Draxler and Hess, 1998). Meteorological input data were obtained from the GDAS archive on the NOAA HYSPLIT website. Vertical velocity was calculated by the model using the vertical velocity fields included with the meteorological data (default HYSPLIT option). The model was run in the ensemble mode with a starting height of $500 \mathrm{~m}$ above ground level. In the ensemble mode, offsets are applied to the meteorological field for each member of the trajectory ensemble. One meteorological grid point in the horizontal dimension and 0.01 sigma units (approx. $250 \mathrm{~m}$ ) in the vertical dimension were used in this work. The resulting trajectory ensemble consists of 27 trajectories for all possible offsets in the $\mathrm{x}^{-}, \mathrm{y}-$, and $\mathrm{z}$-dimension. The air mass history of a $24 \mathrm{~h}$ sample is then described by an ensemble of 648 trajectories, which provides a better description of the variability in the air mass footprint as compared to the single-trajectory mode. Further details on the ensemble procedure can be found in van Pinxteren et al. (2010). In this work it was found that especially the mixed air mass scenarios (see below) can be much better classified this way. The applied trajectory ensemble approach thus facilitated data interpretation. The trajectory ensembles were plotted on a colored map of different land cover classes to aid the categorization of samples into different scenarios.

\section{Results and discussion}

\subsection{Aerosol mass concentration}

Figure 2 shows the time series of the aerosol mass concentration measured at CVAO within the time period of January 2007 and November 2011. The time interval during which intensive field campaigns and trace metal analysis were performed are highlighted in red with open triangles. Nine intensive field campaigns were performed during this period. Four of the campaigns were carried out in the winter months between December and February, lasting on average 6 weeks (i.e., KV II, IV, VI and VII), while the remaining five were performed in the months of May, June, July and November lasting mostly 3 to 4 weeks. Thus, a higher amount of samples were collected during the winter months as otherwise. In total, 317 samples were collected during the intensive campaigns. The temporal variability of the mass concentrations shown in Fig. 2 is indicative of the seasonal trends observed in this region with respect to the aerosol particle loading. As indicated in the figure, during the period between 23 October 2009 and 9 July 2010, sampling was done at a height of $4 \mathrm{~m}$ on the top of a container due to tower maintenance. Thus, during this period, the aerosol mass was strongly influenced by sea spray. With the exception of the above-mentioned time period, the high spikes with mass concentrations above $100 \mu \mathrm{g} \mathrm{m}^{-3}$ are mostly indicative of days with Saharan dust outbreak, which are often observed in the winter months. The low mass concentrations below $30 \mathrm{\mu g} \mathrm{m}^{-3}$ are typical of remote conditions at CVAO, and as can be seen from the time series, this scenario is representative of about $45 \%$ of the year. 


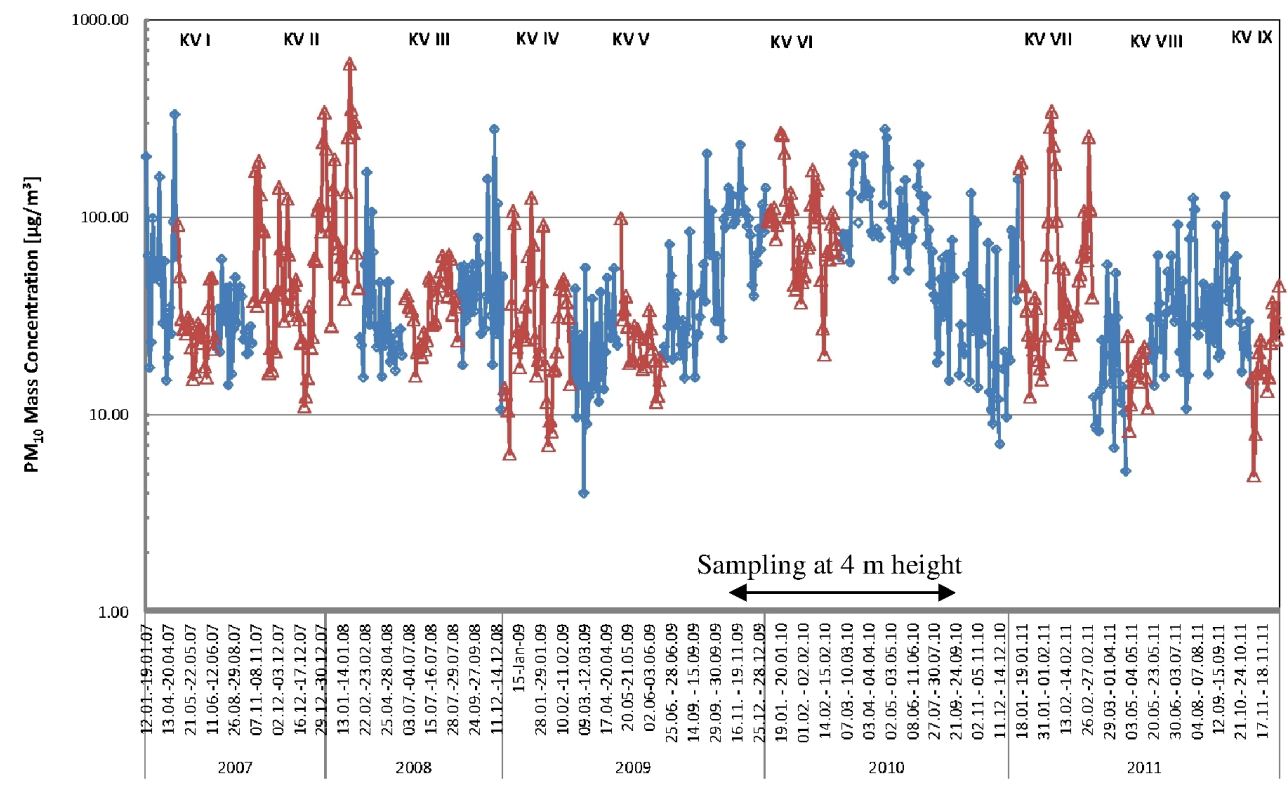

Fig. 2. Time series of $\mathrm{PM}_{10}$ mass concentration at CVAO from January 2007 to November 2011. Red lines with open triangles represent periods of intensive field measurements (9 in total labeled KV I to KV IX).

The variation in the mass concentrations during remote background conditions were found to be correlated with the local wind speed. Average local wind speed at CVAO lies at about $7.3 \pm 2.2 \mathrm{~m} \mathrm{~s}^{-1}$, but might increase to $>13 \mathrm{~m} \mathrm{~s}^{-1}$ during stormy periods, leading to variations of up to $30 \%$ in the aerosol mass concentrations. Similar seasonal trends in aerosol loading with higher mass concentrations during the winter months in comparison to the summer months were observed in other previous studies in this region (Chiapello et al., 1995; Schepanski et al., 2009). This seasonality is attributed to the changing location and structure of the subtropical "Azores" high-pressure system that resides to the north of Cape Verde. According to Kalnay et al. (1996), the highpressure region in winter is broader and covers a larger region from the Caribbean to the Middle East, thus facilitating air mass inflow from the African continent, while in the summer months the region is narrower and restricted to the central Atlantic Ocean, favoring northeast air mass flow from along Europe and the African coast. Despite these high-pressure zones, the air mass inflow also changes within the winter periods such that air masses from Europe and North America are also observed at CVAO. Thus, the remote scenario considered in this work is not restricted to particular seasons but mainly on the daily and weekly variation of the changing air mass direction observed at CVAO.

\subsection{Air mass analysis}

All 317 collected size-resolved samples were characterized and analyzed for their air mass footprints. Of these samples, 100 were of remote conditions; that is, strong air mass influ- ence from the Atlantic, Canary Islands, Europe, and North America. The rest of the samples (217) were related to air mass outflow from, or linked to, the African continent especially through the Saharan Sahel corridor. The larger number of samples in this regime is justified by the timing during which most campaigns were done. Table 2 shows the classification of the samples with respect to their air mass back trajectories.

Although all air masses would contain marine species due to the sampling location, the trace metal and mass concentrations can be different due to the different air mass origins, thus the given classification was made. The trajectory categories were, Atlantic marine (AM), marine over the Canary Islands (MC), marine over Europe (ME), marine over North America (MNA), marine with continental Africa (MCA), Saharan dust only (SS), Saharan dust and urban areas (SU), and lastly Europe and African air mass (EA). The numbers at the bottom of the table represent the total number of times that a given category was observed including mixed situations, e.g., marine air mass over Europe and the Canary Islands. In this study, only the results of the 100 samples pertaining to the remote background conditions at CVAO (AM to MNA) will be discussed. Figure 3 shows exemplary back trajectories of four days that were representative of the air mass categories AM to MNA. Figure 3 a to d represent AM, MC, ME, and MNA conditions, respectively.

The Atlantic air masses mostly arrived from the northwest direction and were most of the time associated with low wind speeds $\left(<6 \mathrm{~m} \mathrm{~s}^{-1}\right)$. The back trajectory analyses reveal that these air masses usually spent little time over urban or arid regions in the last $96 \mathrm{~h}$ prior to their arrival at 
Table 2. Air mass back trajectory classification of all 317 samples with the various categories representing the likely air mass origin in the last $96 \mathrm{~h}$ prior to arrival at CVAO. Table also shows a mixed scenario, in which air mass had crossed both categories before arriving at CVAO.

\begin{tabular}{lrrrrrrrr}
\hline Categories & AM & MC & ME & MNA & MCA & SS & SU & EA \\
\hline Atlantic marine (AM) & 34 & 6 & 2 & 2 & 3 & & & \\
Marine over Canary (MC) & & 27 & & 2 & & 50 & 22 & \\
Marine over Europe (ME) & & & 15 & 2 & & 8 & 25 & \\
Marine over North America (MNA) & & & & 10 & & 11 & & \\
Marine with continental Africa (MCA) & & & & 5 & & & \\
Sahara (SS) & & & & & 37 & 1 & 3 \\
Sahara and urban (SU) & & & & & & 28 & \\
Europe/Africa (EA) & 34 & 33 & 17 & 16 & 8 & 106 & 76 & 27 \\
\hline Total & & & & & & & & \\
\hline
\end{tabular}

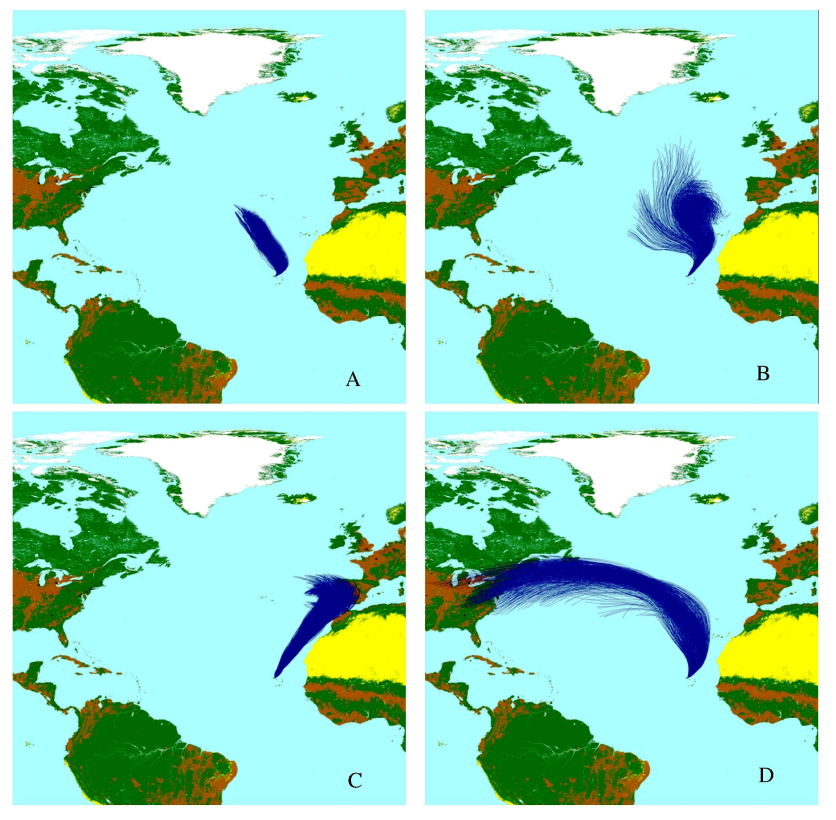

Fig. 3. Examples of $96 \mathrm{~h}$ air mass back trajectory ensembles arriving at CVAO. The blue, yellow, green, and brown colors represent ocean, arid, vegetation, and agricultural landscapes, respectively. (A) 2 May 2011: Atlantic marine. (B) 23 May 2009: Marine over Canary Islands. (C) 4 June 2007: Marine from Europe. (D) 5 February 2009: Marine air mass from North America.

CVAO. On the contrary, the marine air masses over the Canary Islands crossed some arid and urban regions prior to their arrival at CVAO. The marine air mass from Europe had slightly higher wind speeds than both the AM and MC air masses and, as shown below, were mostly of northeast origin. These air masses are also expected to carry fresh anthropogenic emitted particles with them. Lastly, the North America marine air masses also came from the northwest with higher wind speeds than any of the other air masses, and also carried significant amounts of anthropogenically emitted particles with them. These four regimes are discussed be- cause they are the main air mass regimes that account for the remote marine aerosol constitution at CVAO. The regimes as mentioned above have only weak seasonal trends, with more remote conditions observed in the spring and summer months, but no strong seasonal trend like those for mineral dust outbreaks.

\subsection{Trace metal concentration}

The average concentrations (standard deviations in brackets) of the investigated metals for the given air mass categories are shown in Table 3. In obtaining the average concentrations, 34 samples for the MA, 27 for the MC, 15 for the ME, and 10 for the MNA air mass categories were used, while the samples pertaining to the mixed scenarios were not considered. Results show higher variability of the metal concentrations (as shown by the standard deviation values) for MNA air masses in comparison to the others.

This difference may be attributed to the high wind speed $\left(>13 \mathrm{~m} \mathrm{~s}^{-1}\right.$ ) that is associated with this air mass resulting in a greater mixing of different sorts of aerosols from regions with high or low emissions as well as from low and high altitudes. Higher concentrations of $\mathrm{Zn}, \mathrm{Cu}, \mathrm{Sr}, \mathrm{Ba}, \mathrm{Rb}$, and $\mathrm{Cr}$ were observed for MNA air masses in comparison to the others. The higher wind speed and high variability in aerosol content due to long-range transport could explain the higher concentrations of $\mathrm{Sr}, \mathrm{Ba}$, and $\mathrm{Rb}$ since these elements are also emitted from the oceans and to a very small extent $\mathrm{Zn}$, $\mathrm{Cu}$, and $\mathrm{Cr}$ from particle resuspension from the surface waters (Weisel et al., 1984). However, the higher concentrations of $\mathrm{Cu}, \mathrm{Cr}$, and $\mathrm{Zn}$ are mainly from anthropogenic activities since $\mathrm{Zn}$ is a strong surrogate for anthropogenic emissions (Wang et al., 2005) such as from combustion processes.

The concentrations of other crustal elements such as Fe, $\mathrm{Ti}$, and Mn were lower for the MNA but higher for ME and MC air masses. The higher concentrations from these air masses may be due to the shorter distance the air parcel traveled prior to arriving at CVAO, thereby enabling an easy transportation of crustal particles over this distance. A similar tendency to that of the crustal metals was observed for 
Table 3. Average (standard deviation), minimum, and maximum $\mathrm{PM}_{10}$ trace metal concentration at CVAO under remote conditions for the various air mass origins. Samples with mixed scenarios were not considered in obtaining the average values. Values are given in $n g \mathrm{~m}^{-3}$. Range shows the lowest and highest concentrations measured in all the samples irrespective of their air mass origin. Reported column represent mean concentrations and their reported ranges in brackets.

\begin{tabular}{lllllll}
\hline & AM & MC & ME & MNA & Range & Reported \\
\hline $\mathrm{Ti}$ & $0.53(0.72)$ & $0.85(0.6)$ & $0.91(0.99)$ & $0.62(0.27)$ & $0.05-3.17$ & $(0.81-6.02)^{\mathrm{d}}$ \\
$\mathrm{V}$ & $0.14(0.19)$ & $0.31(0.2)$ & $0.31(0.27)$ & $0.13(0.14)$ & $0.01-0.82$ & $(0.45-1.27)^{\mathrm{d}}$ \\
$\mathrm{Cr}$ & $0.37(0.24)$ & $0.49(0.22)$ & $0.31(0.22)$ & $0.53(0.27)$ & $0.01-0.99$ & $0.09(0.03-0.39)^{\mathrm{c}}$ \\
$\mathrm{Mn}$ & $0.12(0.18)$ & $0.35(0.19)$ & $0.21(0.15)$ & $0.09(0.07)$ & $0-0.81$ & $(0.01-1.27)^{\mathrm{d}}$ \\
$\mathrm{Fe}$ & $6.39(7.1)$ & $11.38(6.41)$ & $12.26(10.4)$ & $9.88(7.32)$ & $0.1-25.89$ & $(1.4-24.45)^{\mathrm{d}}$ \\
$\mathrm{Ni}$ & $0.32(0.32)$ & $0.89(0.36)$ & $0.64(0.43)$ & $0.47(0.29)$ & $0.01-1.5$ & $0.18(0.06-0.26)^{\mathrm{a}}$ \\
$\mathrm{Cu}$ & $0.43(0.38)$ & $0.57(0.26)$ & $0.47(0.31)$ & $0.81(0.41)$ & $0.03-1.17$ & $0.7(0.34-1.42)^{\mathrm{a}}$ \\
$\mathrm{Zn}$ & $1.23(1.19)$ & $1.01(0.51)$ & $0.89(0.46)$ & $3.23(1.61)$ & $0.05-4.77$ & $2.56(0.68-4.48)^{\mathrm{a}}$ \\
$\mathrm{Se}$ & $0.06(0.04)$ & $0.1(0.05)$ & $0.08(0.05)$ & $0.04(0.02)$ & $0.01-0.2$ & $0.019(0.018)^{\mathrm{b}}$ \\
$\mathrm{Rb}$ & $0.01(0.01)$ & $0.02(0.02)$ & $0.01(0.02)$ & $0.03(0.02)$ & $0-0.05$ & $0.12(0.04-0.46)^{\mathrm{c}}$ \\
$\mathrm{Sr}$ & $1.14(1.56)$ & $2.09(0.24)$ & $0.66(0.49)$ & $2.63(1.83)$ & $0.01-9.25$ & $0.29(0.27)^{\mathrm{b}}$ \\
$\mathrm{Ba}$ & $0.15(0.27)$ & $0.14(0.1)$ & $0.16(0.16)$ & $0.47(0.35)$ & $0.01-0.93$ & $0.15(0.05-0.25)^{\mathrm{a}}$ \\
$\mathrm{La}$ & $0.01(0.01)$ & $0.03(0.03)$ & $0.02(0.01)$ & $0.01(0.01)$ & $0-0.1$ & $0.00086(0.0007)^{\mathrm{b}}$ \\
$\mathrm{Ce}$ & $0.03(0.02)$ & $0.03(0.04)$ & $0.02(0.03)$ & $0.03(0.03)$ & $0-0.14$ & $0.0016(0.0013)^{\mathrm{b}}$ \\
$\mathrm{Pb}$ & $0.09(0.09)$ & $0.15(0.11)$ & $0.2(0.19)$ & $0.14(0.07)$ & $0.01-0.46$ & $0.6(0.15-1.8)^{\mathrm{a}}$ \\
\hline
\end{tabular}

${ }^{\mathrm{a}}$ Witt et al. (2006), ${ }^{\mathrm{b}}$ Weller et al. (2008) ${ }^{\mathrm{c}}$ Duce et al. (1983), ${ }^{\mathrm{d}}$ Buck et al. (2008).

$\mathrm{Se}, \mathrm{Ni}$, and $\mathrm{V}$, with higher mass concentrations observed for air parcels originating from Europe and the Canary Islands in comparison to those from the other directions. For the other investigated metals including $\mathrm{Pb}, \mathrm{Ce}, \mathrm{La}, \mathrm{Sc}$, no significant difference was found between their concentrations with respect to the air mass back trajectories, implying their values may represent typical background concentrations in this region.

The mean concentrations of $\mathrm{Pb}$ in this work were low $\left(<0.2 \mathrm{ng} \mathrm{m}^{-3}\right.$ and ranged from $\left.0.01-0.46 \mathrm{ng} \mathrm{m}^{-3}\right)$ in comparison to reported concentrations of other studies but were, however, within the concentration range reported elsewhere for remote conditions. Kriews and Schrems (1998) reported median concentrations of $0.32 \mathrm{ng} \mathrm{m}^{-3}\left(0.11-57 \mathrm{ng} \mathrm{m}^{-3}\right)$ for $\mathrm{Pb}$ in aerosol samples collected over the Atlantic Ocean during the Polarstern cruise from Bremerhaven to Punta Arenas (Chile). Huang et al. (1996) reported arithmetic mean concentrations of $0.86 \mathrm{ng} \mathrm{m}^{-3}\left(0.04-3.2 \mathrm{ng} \mathrm{m}^{-3}\right)$ at Bermuda, while $10 \mathrm{yr}$ earlier Wolff et al. (1986) had reported mean concentration of $3.6 \mathrm{ng} \mathrm{m}^{-3}\left(<0.1-8.7 \mathrm{ng} \mathrm{m}^{-3}\right)$ at Bermuda. Witt et al. (2006) reported $\mathrm{Pb}$ concentrations of $0.19 \mathrm{ng} \mathrm{m}^{-3}\left(0.08-27 \mathrm{ng} \mathrm{m}^{-3}\right)$ for remote northern Atlantic, and $0.6 \mathrm{ng} \mathrm{m}^{-3}(0.15-1.8) \mathrm{ng} \mathrm{m}^{-3}$ for remote southern Atlantic during their JCR cruise. The values in this study are in good agreement with those of Witt et al. for remote northern Atlantic conditions, but deviate from those in other remote regions. Comparing the $\mathrm{Pb}$ concentrations from air masses from North America in this work $0.14 \mathrm{ng} \mathrm{m}^{-3}(0.05$ to $0.23 \mathrm{ng} \mathrm{m}^{-3}$ ) to those reported at Bermuda by Huang et al. (1996), it is evident that there has been a significant decrease by about a factor of 3 in the $\mathrm{Pb}$ emissions from North
America over this time period. This decrease is likely related to the phased-out of leaded gasoline and the improvement in technological processes that are related to $\mathrm{Pb}$ emissions.

In all air mass directions, $\mathrm{Fe}$ had the highest mean mass concentration $\left(<12.26 \mathrm{ng} \mathrm{m}^{-3}\right)$, followed by $\mathrm{Zn}, \mathrm{Sr}$, Ti, Ni, $\mathrm{Cu}$, and $\mathrm{Cr}\left(<0.53 \mathrm{ng} \mathrm{m}^{-3}\right)$. The lowest concentration was observed for $\mathrm{Co}\left(<10 \mathrm{pg} \mathrm{m}^{-3}\right)$, La, and $\mathrm{Se}\left(<100 \mathrm{pg} \mathrm{m}^{-3}\right)$. The concentrations of the other elements were between these extremes. The obtained concentration range of these elements is within the same order of magnitude as those reported for other remote regions in the Atlantic and other open oceans. Witt et al. (2006) reported mean concentrations and ranges for $\mathrm{Cu}, 0.7 \mathrm{ng} \mathrm{m}^{-3}\left(0.34-1.42 \mathrm{ng} \mathrm{m}^{-3}\right)$, $\mathrm{Ni}, 0.18 \mathrm{ng} \mathrm{m}^{-3}\left(0.06-0.26 \mathrm{ng} \mathrm{m}^{-3}\right)$, and $\mathrm{Zn}, 2.56 \mathrm{ng} \mathrm{m}^{-3}$ $\left(0.68-4.48 \mathrm{ng} \mathrm{m}^{-3}\right)$ for remote southern Atlantic conditions. For the remote northern Atlantic, concentrations for $\mathrm{Cu}$ of $0.58 \mathrm{ng} \mathrm{m}^{-3}\left(0.47-0.7 \mathrm{ng} \mathrm{m}^{-3}\right), \mathrm{Ni}$ of $0.22 \mathrm{ng} \mathrm{m}^{-3}(0.01-$ $\left.0.42 \mathrm{ng} \mathrm{m}^{-3}\right), \mathrm{Zn}$ of $2.05 \mathrm{ng} \mathrm{m}^{-3}\left(1.95-2.15 \mathrm{ng} \mathrm{m}^{-3}\right)$, and Ba of $0.42 \mathrm{ng} \mathrm{m}^{-3}\left(0.4-0.44 \mathrm{ng} \mathrm{m}^{-3}\right)$ were reported. The concentrations in this study were in good agreement with those reported by Witt et al. (2006) for remote northern Atlantic conditions despite the few datasets used by Witt et al. (2006) compared to those used in this study. Duce et al. (1983) reported mean concentrations for remote conditions at Enewetak of $0.04 \mathrm{ng} \mathrm{m}^{-3}$ for $\mathrm{Cu}, 0.17 \mathrm{ng} \mathrm{m}^{-3}$ for $\mathrm{Zn}, 0.08 \mathrm{ng} \mathrm{m}^{-3}$ for $\mathrm{V}, 0.12 \mathrm{ng} \mathrm{m}^{-3}$ for $\mathrm{Pb}$, and $0.16 \mathrm{ng} \mathrm{m}^{-3}$ for $\mathrm{Zn}$. Their mean values were generally lower than those obtained in this work but, however, fall within the concentration range observed in this study. Similarly, Spokes et al. (2001) reported slightly higher concentrations than those of Duce et al. (1983) for remote marine conditions at Mace Head, but 

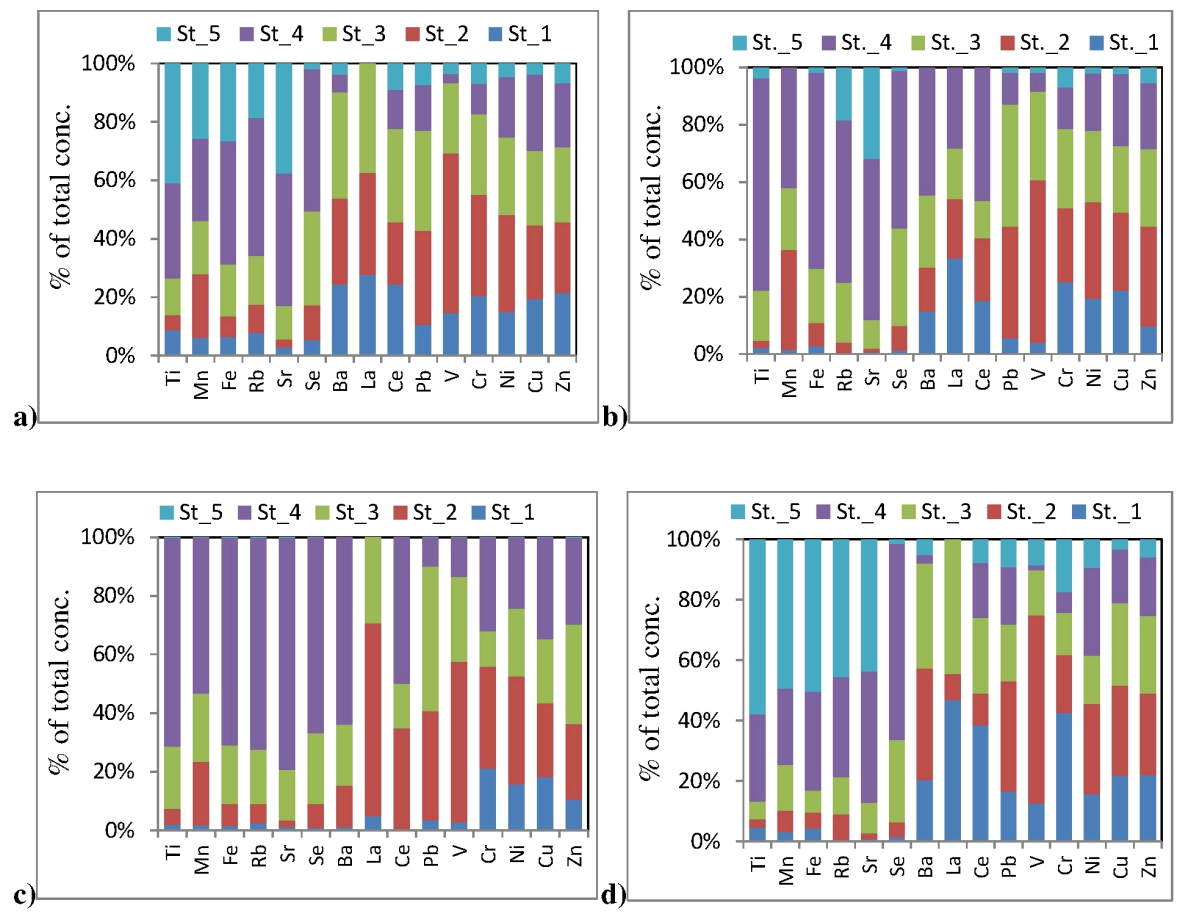

Fig. 4. Distribution of investigated elements according to their size fractions for all four air mass directions: (a) AM, (b) MC, (c) ME, and (d) MNA.

their values are still within the concentration range obtained in this work. Weller et al. (2008) reported concentrations that were lower than those in this work for $\mathrm{Se}, \mathrm{Ce}$, and $\mathrm{La}$, which is expected due to lower anthropogenic influence in Antarctica compared to the CVAO. The values for $\mathrm{Fe}$, Ti, and Mn were within the range of values observed by Buck et al. (2010b) during their CLIVAR ship cruise along the northern tropical Atlantic.

Concentrations of metals from crustal origin were slightly higher in air masses from Europe and the Canary Islands due to the short residence time from emission source and their likely passage over arid regions over the Canary Islands prior to arrival at the station, while elements known to be emitted from anthropogenic processes such as $\mathrm{Cu}, \mathrm{Zn}$, and $\mathrm{Cr}$ were of long-range transport with higher concentrations often observed from air masses originating from North America. On the other hand, higher concentrations of $\mathrm{Ni}$ were often observed from air masses originating from Europe, which reflects results from some global estimates reported by Pacyna and Pacyna (2001).

In summary, we found reasonable agreement on the data of $\mathrm{Pb}, \mathrm{Cu}, \mathrm{Zn}, \mathrm{Se}$, and $\mathrm{Ba}$ with those reported in the literature; however, we observe slightly higher concentrations for $\mathrm{Ni}, \mathrm{Cr}$, and $\mathrm{Sr}$, and lower values for $\mathrm{Fe}, \mathrm{Mn}$, Ti, and $\mathrm{V}$. Higher $\mathrm{Cr}, \mathrm{Zn}$, and $\mathrm{Cu}$ concentrations were observed only in MNA air masses, while $\mathrm{Fe}, \mathrm{Mn}, \mathrm{Ti}, \mathrm{Ni}$, and $\mathrm{V}$ were higher in $\mathrm{ME}$ and $\mathrm{MC}$ air masses. These results were comparable to other remote marine regions in the Pacific or southern At- lantic Ocean, but are the first long-term results for trace metal concentrations in remote northern tropical Atlantic marine aerosols. The small concentration variations between this work and other reported works, however, can be explained in terms of the different dominant air mass origins that strongly influence the remote environment. Although there have been other studies of trace metal concentration in other remote marine environments as cited above, we are not aware of any long-term studies in the northern Atlantic of size-resolved data that would allow assessment of compositional variability and aerosol solubility studies as in the present work.

\subsection{Size-resolved analysis}

The size-resolved analysis of the investigated metals for the given air mass footprints is shown in Fig. 4. Fe, Ti, Sr, Rb, and Mn were mostly found on stages 4 and 5 (1.2-10 $\mu \mathrm{m}) \mathrm{im}$ plying that most of the mass of these metals originated from a common source of coarse aerosol. This tendency was observed for all of the air mass directions. About $85 \%$ of $\mathrm{Sr}$, $40-60 \%$ of $\mathrm{Mn}$, and $70-75 \%$ of $\mathrm{Fe}, \mathrm{Rb}$, and $\mathrm{Ti}$ was present in the coarse mode, with a small increase in their mass fraction by about $10 \%$ during MNA air mass influence. This increase may also be attributed to the long-range transport and thus variability of this air mass. Despite the prevalence in the larger particles, their presence in the submicron particles is indicative of the presence of particles from combustion and or industrial sources in addition to resuspension and 
frictional process from road traffic. Fine-mode Mn may originate from high-temperature combustion processes of $\mathrm{Mn}$ rich fuels as well as from steel production. $\mathrm{Ba}$ and $\mathrm{Ce}$ were found on all stages with a higher fraction on stages four and three. This implies that these elements were of mixed origin, such as from crustal, oceanic and anthropogenic sources.

In the fine mode, $\mathrm{V}, \mathrm{Cr}, \mathrm{Ni}, \mathrm{Cu}, \mathrm{Zn}, \mathrm{La}$, and $\mathrm{Pb}$ were mostly found - in particular on impactor stages 2 and 3 (0.1$0.52 \mu \mathrm{m})$. However, more than $20 \%$ of their mass was also found in coarse-mode particles. Their broad existence is indicative of their multiple source origin, including a combination of long-range transport due to the long atmospheric residence time of the submicron particles, and vehicular and industrial emissions. With the phase-out of leaded gasoline, lead concentrations may likely be of nonautomotive sources related to metal industries (Allen et al., 2001; Guieu et al., 2002), from coal and waste combustion, (Pacyna and Pacyna, 2001) or from resuspended contaminated soils.

For a few elements - Cr, Ni, $\mathrm{Cu}$ and $\mathrm{Zn}-$ less than $20 \%$ of their mass was found in stage $1(50-140 \mathrm{~nm})$. The presence of such bioactive trace metals in the submicron particle range is usually attributed to their condensation on small particles after gas-phase emissions from anthropogenic sources (Arimoto et al., 1989). However, recent findings also suggest that these metals may also have some oceanic origin coming from organometallic compounds in the ocean or from marine colloids (Orellana et al., 2011; Guo et al., 2000). Organic compounds containing these metals can also be transported over long range from the continents or released from the ocean's surface microlayer through blasting during stormy conditions, thereby releasing them to the atmosphere. High organic matter concentrations in stage 1 were observed in previous studies at CVAO (Müller et al., 2010). Se showed a significant coarse-mode fraction. This occurrence may be due to the presence of biogenic material or the deposition of gaseous forms of Se on coarse particle surfaces. The demarcation between the elements present in the fine- and coarsemode particles in all air mass categories is better illustrated in Fig. 5 in terms of the $\mathrm{PM}_{1.2} / \mathrm{PM}_{10}$ ratio. $\mathrm{PM}_{1.2}$ is obtained as the sum of the first three impactor stages while $\mathrm{PM}_{10}$ is the sum of all impactor stages. The $\mathrm{PM}_{1.2} / \mathrm{PM}_{10}$ ratios show a uniform profile for the various air mass origins.

The deviations from the pattern are only observed for $\mathrm{Mn}$, $\mathrm{Ba}, \mathrm{La}$, and $\mathrm{Ce}$. Most of the metals were present in the fine mode exhibiting high $\mathrm{PM}_{1.2} / \mathrm{PM}_{10}$ ratios especially for $\mathrm{V}$, $\mathrm{Cr}, \mathrm{Ni}, \mathrm{Cu}, \mathrm{Zn}$, and $\mathrm{Pb}$. For $\mathrm{Mn}$ the different tendencies were observed for the different air mass origin, implying a significant amount of fine-mode $\mathrm{Mn}$ particles were emitted from air masses originating from Europe and also those crossing the Canary Islands. The variation in the fine- to coarse-mode ratio for $\mathrm{Ba}$ and $\mathrm{Ce}$ in the different air mass origins imply that these elements had many origins or possessed significant spatial variability. In most cases, the dominantly finemode metals were concentrated on the second and third impactor stages $(0.14-1.2 \mu \mathrm{m})$ and can be attributed to long-

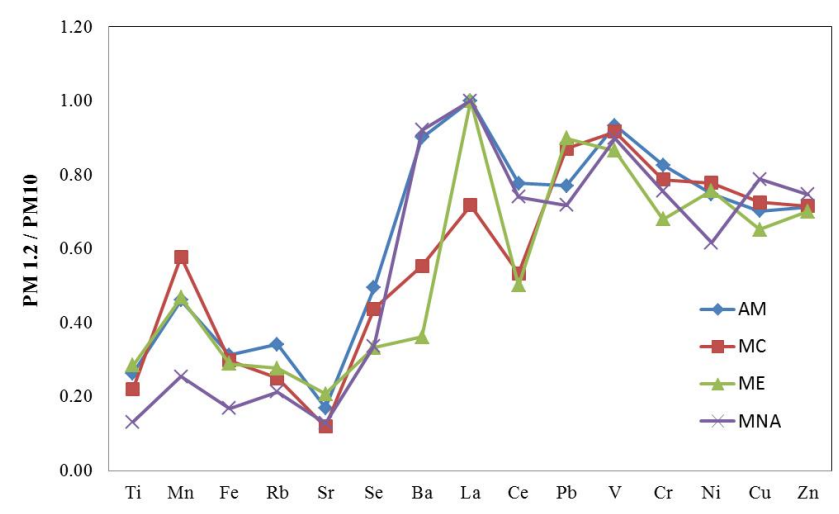

Fig. 5. Fine $\left(\mathrm{PM}_{1.2}\right)$ to coarse $\left(\mathrm{PM}_{10}\right)$ ratios for measured trace elements in the four major air mass footprints representative of the aerosol background at CVAO.

range transport. Metals of crustal or oceanic origins such as $\mathrm{Ti}, \mathrm{Fe}$, and $\mathrm{Sr}$ show very low $\mathrm{PM}_{1.2} / \mathrm{PM}_{10}$ ratio, which is indicative of their coarse-mode presence.

\subsection{Enrichment factor analysis}

Crustal enrichment factor (EF) analysis was applied to estimate the contributions of crustal dust to the obtained elemental concentrations in our samples. For this analysis Ti was used as marker for mineral dust. Wedepohl (1995) compilation of continental crust composition was used to calculate enrichment factors and crustal contribution on elemental concentrations.

For an element $(Z)$ in a sample, the EF relative to $\mathrm{Ti}$ is given as

$\mathrm{EF}=\frac{(Z / \mathrm{Ti})_{\text {Sample }}}{(Z / \mathrm{Ti})_{\text {Crust }}}$.

An enrichment factor above 2 but less than 10 is considered as moderate enrichment or might originate from other crustal material with different composition from the chosen reference material for this element. Elements with EF above 10 are considered enriched, and below 0.70 signifies depletion in comparison to the composition of the reference source. Enrichment factors between 0.70 and 2 are considered to be similar and within the error range to the reference source, implying that the elements with such factors might have originated from such a source. Figure 6 shows the enrichment factors with respect to Ti for each size fraction and $\mathrm{PM}_{10}$ for the measured elements in the four main air mass directions representative of the remote conditions.

The elemental enrichment factors show similar trends in all four air mass directions with a reduction in the EFs with increasing particle size. The coarse particles were thus related to crustal emissions in comparison to the fine-mode particles. From the elemental enrichment factors, three main groups of element could be observed. 

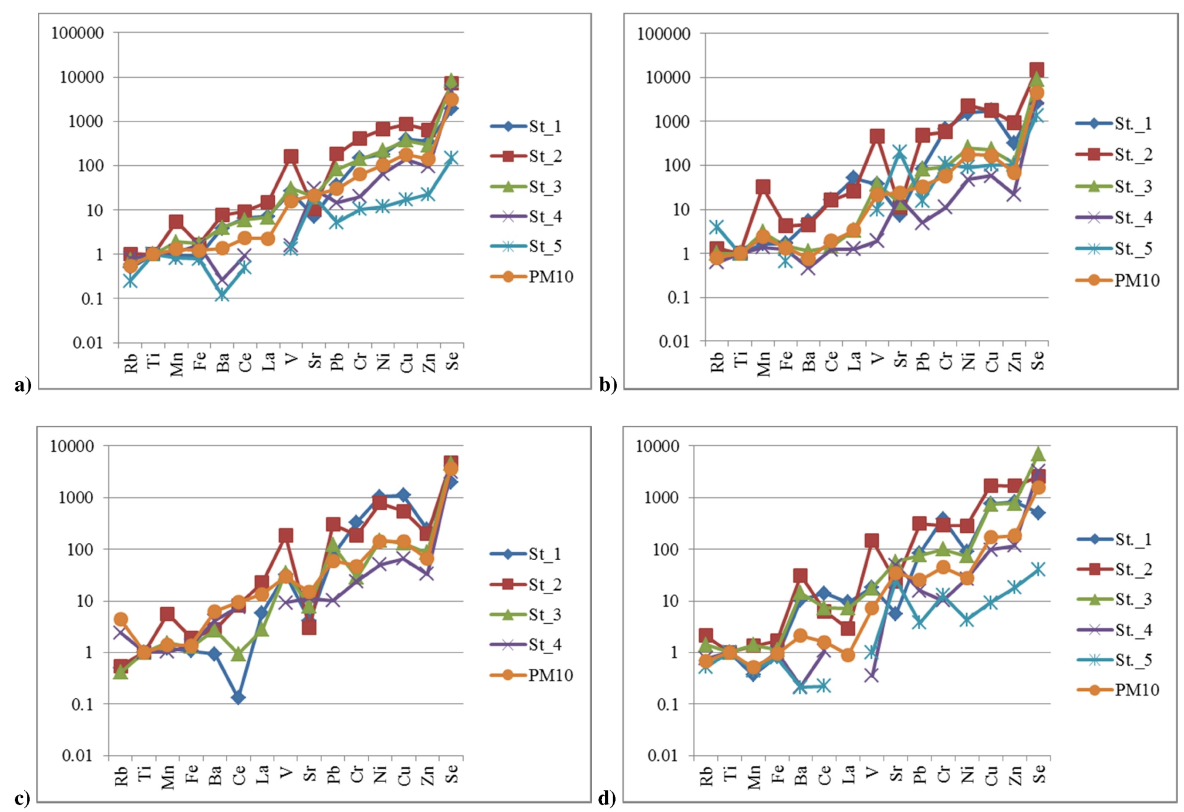

Fig. 6. Enrichment factors of the measured elements in each impactor stage and each air mass origin from (a) AM, (b) MC, and (c) ME to (d) MNA.

i. Group one elements include $\mathrm{Fe}, \mathrm{Mn}, \mathrm{Co}$, and $\mathrm{Rb}$. These elements had enrichment factors between 0.8 and 2 on most of the stages in all air mass directions. Their $\mathrm{PM}_{10}$ enrichment factors are also in this range indicating that these elements are associated with particles that became airborne by soil dispersion or other crustal sources. Mn showed higher EFs on stages 2 and 3 for the Atlantic marine air masses, indicating that other sources than mineral dust could contribute to its presence such as from iron and steel industries (Hacisalihoglu et al., 1991). The release of Mn during smelting and use of methylcyclopentadienyl manganese tricarbonyl as an octane enhancer in unleaded car fuels may partially account for enhanced levels of fine-mode aerosol Mn seen in polluted air (Wallace and Slonecker, 1997; Pfeifer et al., 1999). This could be associated to long-range transport from Europe or North America since particles in this size range (140 nm to $1200 \mathrm{~nm}$, stages 2 and 3) can live longer than 8 days in the atmosphere. Although we are aware of the existence of anthropogenic Fe and from observations made by other works (Siefert et al., 1999; Sholkovitz et al., 2012), our data do not show high $\mathrm{Fe}$ enrichment. This would suggest that anthropogenic iron was not high for the air mass categories considered in this study. However, it is worth noting that the EFs in this work are estimated from average values, which may underestimate or average out episodes of high $\mathrm{Fe}$ enrichment.

ii. Group two elements include $\mathrm{Ba}, \mathrm{Ce}, \mathrm{La}, \mathrm{Sr}$, and $\mathrm{V}$. These elements had enrichment factors between 2 and
20, indicating they were of mixed sources, including crustal, marine or anthropogenic sources. The lower enrichment factors were observed mostly in the case of marine air masses (Fig. 6a and b), indicating the elements were likely of crustal origin, while the higher Efs were mostly observed in air masses that crossed $\mathrm{Eu}-$ rope or North America (Fig. 6c and d) before arriving at CVAO indicating that these elements were also of anthropogenic origin. The high enrichment factor for $\mathrm{V}$ was mostly observed on the second and third stages. The main source of atmospheric noncrustal $\mathrm{V}$ is residual oil burning (Zoller et al., 1973) and particles from oilburning processes do have long atmospheric life times due to their small particles sizes. The high $\mathrm{Sr}$ enrichment factors can be attributed to its marine (Weller et al., 2008) sources.

iii. Group three elements include $\mathrm{Pb}, \mathrm{Cr}, \mathrm{Ni}, \mathrm{Cu}, \mathrm{Zn}$ and Se. These elements had very high enrichment factors in all air mass directions. The high values are an indication of strong anthropogenic influence. Atmospheric $\mathrm{Pb}$ originates mostly from smelters or from the burning of unleaded fuel as well as from waste and coal combustion. In general, combustion processes are the major contributors for $\mathrm{Pb}$, which is consistent with its dominant presence in the very fine mode. Despite the phaseout of leaded fuel, residual levels of $\mathrm{Pb}$ in air originating from $\mathrm{Pb}$ in gasoline are expected to persist in continental particles for decades (Brewer and Belzer, 2001). Pb can also originate from resuspension of contaminated crustal material (Wang et al., 2005), thus explaining the 
lower EF with decreasing particle size observed for $\mathrm{Pb}$. $\mathrm{Ni}$ and $\mathrm{Cr}$ are also emitted via combustion processes. As observed above, their higher enrichment in the fine mode is indicative of emissions from combustion processes (Steinsberger et al., 1994). Their occurrence in the coarse mode may be related to natural emissions including windblown soil and vegetation, or to a very small extent sea salt. Road traffic has also been found to contribute to $\mathrm{Ni}$ emissions, with mean emission factors of about $0.07 \mathrm{mg} \mathrm{kg}^{-1}$ (of unleaded petrol and diesel) in Europe (David Hjortenkrans, 2008; EEA, 2007), suggesting that road traffic pollution might not be negligible. Similarly, the very high $\mathrm{EF}$ for $\mathrm{Cu}$ and $\mathrm{Zn}$ signifies their anthropogenic origin. $\mathrm{Cu}$ and $\mathrm{Zn}$ are elements that are typical of emissions from anthropogenic activities such as fly ash, waste incineration, and road traffic (Pacyna, 1984; Pacyna and Pacyna, 2001). Their enrichment in the coarse mode indicates that the coarse-mode particles may be originating from lower temperature industrial processes or from erosion of $\mathrm{Zn}$ rich soils.

According to global emission estimates from Pacyna and Pacyna (2001), $\mathrm{Zn}$ and $\mathrm{Cu}$ are the highest emitted elements from non-ferrous metal production with about 40872 (Zn) and $18071(\mathrm{Cu}) \mathrm{tn} \mathrm{yr}^{-1}$, respectively. $\mathrm{Cu}$ and $\mathrm{Zn}$ may also have oceanic sources, especially when associated with marine colloids that may be released from the marine microlayer or also from resuspension (Weisel et al., 1984).

Se had the highest enrichment factor in all air mass directions and on all impaction stages, suggesting that its presence in this region is not related to crustal fractionation or erosion. A similar observation was made by Arimoto et al. (1989, 1995) over the Pacific and North Atlantic oceans, respectively. Coal-fired power plants and copper smelters apparently are important anthropogenic sources for Se (Germani et al., 1981; Andren et al., 1975) and may contribute to the observed concentrations in this region, especially for air masses that crossed Europe or North America before arriving at CVAO. Other natural sources like sea spray (Mosher and Duce, 1987) or volcanoes have also been suggested (Cunningham and Zoller, 1981). The sea spray could certainly account for a given fraction of the observed concentrations since Se was observed in all air mass directions. However, volcanic sources may be rather negligible since very few active volcanoes are positioned along the air mass directions observed in the work. In Cape Verde the active volcano of Fogo lies southeast of CVAO; thus, its influence on the remote Se concentrations observed at CVAO may be neglected. It has been postulated that heterogeneous reactions are important determinants of Se concentrations in aerosol particles. According to Mosher and Duce (1983), approximately 10 to $25 \%$ of the Se in nonurban regions resides in the vapor phase and a significant amount of the gas-phase Se evolve from the ocean, with a subsequently occurrence of a gas to particle conversion in the atmosphere. Although the mechanisms responsible for this evolution were not specified, they inferred that the processes responsible for the flux of Se from the ocean to the atmosphere are biologically mediated. Amouroux et al. (2001) showed that the production of gaseous Se species coincide with phytoplankton blooms responsible for dimethyl sulfide (DMS) emission. They observed that the sulfur atom in DMS can be substituted by Se, implying a close correlation between DMS and Se. Lately, Weller et al. (2008) observed a significant correlation between Se and the end products of photochemical DMS oxidation, methane sulfonate and non-sea-salt sulfate, suggesting that atmospheric Se should be closely coupled to the DMS production. Conclusively, the enriched Se in the particles can therefore be attributed to oceanic sources for the coarse and fine fraction as well as long-range-transported aerosol for the particles in the fine fraction.

\section{Conclusions}

Size-resolved trace metal concentrations of 15 elements in aerosol particles at CVAO under remote background conditions were investigated in this study. The identification of the main air mass origins that influence the remote marine aerosol in the northern tropical Atlantic was performed. For this analysis a total of 100 samples collected over a 4 yr time period from 2007 to 2011 were used. Our observation revealed that remote conditions were representative of $45 \%$ of the of the yearly aerosol conditions at CVAO, while Saharan dust and air mass originating from continental Africa accounted for the remaining $55 \%$ of the year. The results show very low trace metal concentrations as compared to continental trace metal concentrations but, however, fall in the same order of magnitude as those observed in other remote oceanic regions. Higher metal concentrations were observed for air masses that had crossed North America or Europe before arriving at CVAO in comparison to Atlantic marine air mass. In general, the air mass from North America was also associated with high wind speeds $\left(>13 \mathrm{~m} \mathrm{~s}^{-1}\right)$ leading not only to higher metal concentrations but also to higher aerosol particle concentration. The size-resolved data of the metals show distinct distribution of the elements, indicating that the particles resulted from disparate processes. In particular, elements from natural sources were primarily associated with coarse particles, although other natural sources like oceanic emissions might have also been responsible for some fine-mode particles. Elements from anthropogenic sources were found in the fine-mode particles. Enrichment factor analysis was performed to evaluate the natural as opposed to the anthropogenic sources of the metals. High enrichment factors were observed for $\mathrm{Zn}, \mathrm{Cu}, \mathrm{Ni}, \mathrm{Cr}, \mathrm{Pb}$, and $\mathrm{Se}$, indicating their dominant anthropogenic over natural processes. In the case of Se, biogenic sources might have also been important. Elements such as $\mathrm{Mn}, \mathrm{Fe}, \mathrm{Ba}$, and $\mathrm{Rb}$ had low enrichment factors, indicating their predominant natural source such as soil erosion 
or sea spray. Our observation over a $5 \mathrm{yr}$ period at CVAO shows that the long-range transport from North America as well as Europe plays a key role in the supply of essential bioactive metals such as $\mathrm{Zn}, \mathrm{Cu}$, and Fe into the northern tropical Atlantic Ocean, which are constantly required for the metabolism of marine microorganisms. With emissions from anthropogenic activities dominating the trace metal budget in remote aerosols and thus the life of marine organisms in this region, it is important that caution and consideration are taken when making environmental policies on anthropogenic activities in Europe, Africa, and North America. These results are expected to be representative of the trace metal content deposited into the ocean over this region and may provide useful hints on assessing the impact of these metals on processes at the ocean surface or water columns via model studies.

This work provides the first long-term size-resolved trace metal studies with a larger dataset for remote marine aerosol in the northern tropical Atlantic. These results could serve as a starting point for initializing model runs and estimating yearly flows of these metals in this region of the Atlantic Ocean since these results are representative of events that occurred over the last five years with some seasonal trends. Obtaining yearly flows of total and bioavailable aerosol trace metal content in this region would be useful in assessing the global input of atmospheric nutrients into the northern tropical Atlantic.

Acknowledgements. The authors would like to thank Helder Timas Nascimento and Luis Mendes Neves for their support during the routine sample collection at the CVAO. We would also like to thank the laboratory assistants for their technical support, and the BMBF for the financial support through the SOPRAN projects 03F0462J and 03F0611J. The authors thank the two anonymous reviewers for their useful comments.

Edited by: R. Krejci

\section{References}

Allen, A. G., Nemitz, E., Shi, J. P., Harrison, R. M., and Greenwood, J. C.: Size distributions of trace metals in atmospheric aerosols in the United Kingdom, Atmos. Environ., 35, 4581-4591, 2001.

Amouroux, D., Liss, P. S., Tessier, E., Hamren-Larsson, M., and Donard, O. F. X.: Role of oceans as biogenic sources of selenium, Earth Planet. Sc. Lett., 189, 277-283, 2001.

Andren, A. W., Klein, D. H., and Talmi, Y.: Selenium in coalfired steam plant emissions, Environ. Sci. Technol., 9, 856-858, doi:10.1021/es60107a002, 1975.

Arimoto, R., Duce, R. A., and Ray, B. J.: Concentrations, sources and air-sea exchange of trace elements in the atmosphere over the Pacific Ocean, SEAREX, Chemical Oceanography, edited by: Riley, J. P., Chester, R., and Duce, R. A., 107-149, Academic, San Diego, Calif., 1989.

Arimoto, R., Duce, R. A., Ray, B. J., Ellis, W. G., Cullen, J. D., and Merrill, J. T.: Trace-Elements in the Atmosphere over the North-Atlantic, J. Geophys. Res.-Atmos., 100, 1199-1213, doi:10.1029/94jd02618, 1995.

Bertine, K. K. and VernonClark, R.: Elemental composition of the colloidal phase isolated by cross-flow filtration from coastal seawater samples, Mar. Chem., 55, 189-204, 1996.

Brewer, R. and Belzer, W.: Assessment of metal concentrations in atmospheric particles from Burnaby Lake, British Columbia, Canada, Atmos. Environ., 35, 5223-5233, 2001.

Buck, C. S., Landing, W. M., and Resing, J. A.: Particle size and aerosol iron solubility: A high-resolution analysis of Atlantic aerosols, Mar. Chem., 120, 14-24, doi:10.1016/j.marchem.2008.11.002, 2010a.

Buck, C. S., Landing, W. M., Resing, J. A., and Measures, C. I.: The solubility and deposition of aerosol $\mathrm{Fe}$ and other trace elements in the North Atlantic Ocean: Observations from the A16N CLIVAR/CO2 repeat hydrography section, Mar. Chem., 120, 57-70, doi:10.1016/j.marchem.2008.08.003, 2010b.

Chiapello, I., Bergametti, G., Gomes, L., Chatenet, B., Dulac, F., Pimenta, J., and Suares, E. S.: An Additional Low Layer Transport of Sahelian and Saharan Dust over the North-Eastern Tropical Atlantic, Geophys. Res. Lett., 22, 3191-3194, 1995.

Chiapello, I., Bergametti, G., Chatenet, B., Bousquet, P., Dulac, F., and Soares, E. S.: Origins of African dust transported over the northeastern tropical Atlantic, J. Geophys. Res.-Atmos., 102, 13701-13709, 1997.

Chiapello, I., Prospero, J. M., Herman, J. R., and Hsu, N. C.: Detection of mineral dust over the North Atlantic Ocean and Africa with the Nimbus 7 TOMS, J. Geophys. Res.-Atmos., 104, 92779291, 1999.

Chiapello, I., Moulin, C., and Prospero, J. M.: Understanding the long-term variability of African dust transport across the Atlantic as recorded in both Barbados surface concentrations and large-scale Total Ozone Mapping Spectrometer (TOMS) optical thickness, J. Geophys. Res.-Atmos., 110, D18s10 doi:10.1029/2004jd005132, 2005.

Cunningham, W. C. and Zoller, W. H.: The Chemical-Composition of Remote Area Aerosols, J. Aerosol Sci., 12, 367, 1981.

David Hjortenkrans: Road traffic metals - sources and emissions, Dissertation, University of Kalmar, Sweden, ISBN 97891-85993-07-9, 2008.

Draxler, R. R. and Hess, G. D.: An overview of the HYSPLIT_4 modelling system of trajectories, dispersion, and deposition, Australian Meteorological Magazine, 47, 295-308, 1998.

Duce, R. A., Ray, B. J., Hoffman, G. L., and Walsh, P. R.: TraceMetal Concentration as a Function of Particle-Size in Marine Aerosols from Bermuda, Geophys. Res. Lett., 3, 339-342, 1976.

Duce, R. A., Arimoto, R., Ray, B. J., Unni, C. K., and Harder, P. J.: Atmospheric Trace-Elements at Enewetak-Atoll .1. Concentrations, Sources, and Temporal Variability, J. Geophys. Res.-Oc. Atm., 88, 5321-5342, 1983.

Duce, R. A., Liss, P. S., Merrill, J. T., Atlas, E. L., Buat-Menard, P., Hicks, B. B., Miller, J. M., Prospero, J. M., Arimoto, R., Church, T. M., Ellis, W., Galloway, J. N., Hansen, L., Jickells, T. D., Knap, A. H., Reinhardt, K. H., Schneider, B., Soudine, A., Tokos, J. J., Tsunogai, S., Wollast, R., and Zhou, M.: The atmospheric input of trace species to the world ocean, Global Biogeochem. Cy., 5, 193-259, doi:10.1029/91gb01778, 1991.

EEA: EMEP/CORINAIR Emission Inventory Guidebook, Technical Report, 16, European Environmental Agency, Copenhagen, 
2007.

Galloway, J. N., Thornton, J. D., Norton, S. A., Volchok, H. L., and Mclean, R. A. N.: Trace-Metals in Atmospheric Deposition - a Review and Assessment, Atmos. Environ., 16, 1677-1700, 1982.

Germani, M. S., Small, M., Zoller, W. H., and Moyers, J. L.: Fractionation of Elements during Copper Smelting, Environ. Sci. Technol., 15, 299-305, 1981.

Guieu, C., Loye-Pilot, M. D., Ridame, C., and Thomas, C.: Chemical characterization of the Saharan dust end-member: Some biogeochemical implications for the western Mediterranean Sea, J. Geophys. Res.-Atmos., 107, 4258, doi:10.1029/2001jd000582, 2002.

Guo, L. D., Santschi, P. H., and Warnken, K. W.: Trace metal composition of colloidal organic material in marine environments, Mar. Chem., 70, 257-275, 2000.

Hacisalihoglu, G., Balkas, T. I., Tuncel, S. G., Herman, D. H., Olmez, I., and Tuncel, G.: Trace-Element Composition of the Black-Sea Aerosols, Deep-Sea Res., 38, S1255-S1266, 1991.

Hand, J. L., Mahowald, N. M., Chen, Y., Siefert, R. L., Luo, C., Subramaniam, A., and Fung, I.: Estimates of atmospheric-processed soluble iron from observations and a global mineral aerosol model: Biogeochemical implications, J. Geophys. Res.-Atmos., 109, D17205, doi:10.1029/2004jd004574, 2004.

Huang, S. L., Arimoto, R., and Rahn, K. A.: Changes in atmospheric lead and other pollution elements at Bermuda, J. Geophys. Res.Atmos., 101, 21033-21040, 1996.

Johansen, A. M., Siefert, R. L., and Hoffmann, M. R.: Chemical characterization of ambient aerosol collected during the southwest monsoon and intermonsoon seasons over the Arabian Sea: Anions and cations, J. Geophys. Res.-Atmos., 104, 2632526347, 1999.

Kalnay, E., Kanamitsu, M., Kistler, R., Collins, W., Deaven, D., Gandin, L., Iredell, M., Saha, S., White, G., Woollen, J., Zhu, Y., Chelliah, M., Ebisuzaki, W., Higgins, W., Janowiak, J., Mo, K. C., Ropelewski, C., Wang, J., Leetmaa, A., Reynolds, R., Jenne, R., and Joseph, D.: The NCEP/NCAR 40-year reanalysis project, B. Am. Meteorol. Soc., 77, 437-471, 1996.

Kriews, M. and Schrems, O.: Spatial distribution of trace elements in aerosols over the Atlantic Ocean, J. Aerosol Sci., 29, Supplement 2, S735-S736, hdoi:10.1016/S0021-8502(98)90550-X, 1998.

Lawler, M. J., Finley, B. D., Keene, W. C., Pszenny, A. A. P., Read, K. A., von Glasow, R., and Saltzman, E. S.: Pollutionenhanced reactive chlorine chemistry in the eastern tropical Atlantic boundary layer, Geophys. Res. Lett., 36, L08810, doi:10.1029/2008g1036666, 2009.

Lee, J. D., McFiggans, G., Allan, J. D., Baker, A. R., Ball, S. M., Benton, A. K., Carpenter, L. J., Commane, R., Finley, B. D., Evans, M., Fuentes, E., Furneaux, K., Goddard, A., Good, N., Hamilton, J. F., Heard, D. E., Herrmann, H., Hollingsworth, A., Hopkins, J. R., Ingham, T., Irwin, M., Jones, C. E., Jones, R. L., Keene, W. C., Lawler, M. J., Lehmann, S., Lewis, A. C., Long, M. S., Mahajan, A., Methven, J., Moller, S. J., Müller, K., Müller, T., Niedermeier, N., O’Doherty, S., Oetjen, H., Plane, J. M. C., Pszenny, A. A. P., Read, K. A., Saiz-Lopez, A., Saltzman, E. S., Sander, R., von Glasow, R., Whalley, L., Wiedensohler, A., and Young, D.: Reactive Halogens in the Marine Boundary Layer (RHaMBLe): the tropical North Atlantic experiments, Atmos. Chem. Phys., 10, 1031-1055, doi:10.5194/acp-10-1031-
2010, 2010.

Morel, F. M. M., Milligan, A. J., and Saito, M. A.: 6.05 - Marine Bioinorganic Chemistry: The Role of Trace Metals in the Oceanic Cycles of Major Nutrients, in: Treatise on Geochemistry, edited by: Heinrich, D. H. and Karl, K. T., Pergamon, Oxford, 113-143, 2003.

Mosher, B. W. and Duce, R. A.: Vapor phase and particulate selenium in the marine atmosphere J. Geophys. Res., 88, 6761-6768, doi:10.1029/JC088iC11p06761, 1983.

Mosher, B. W. and Duce, R. A.: A Global Atmospheric Selenium Budget, J. Geophys. Res.-Atmos., 92, 13289-13298, 1987.

Müller, K., Lehmann, S., van Pinxteren, D., Gnauk, T., Niedermeier, N., Wiedensohler, A., and Herrmann, H.: Particle characterization at the Cape Verde atmospheric observatory during the 2007 RHaMBLe intensive, Atmos. Chem. Phys., 10, 2709-2721, doi:10.5194/acp-10-2709-2010, 2010.

Orellana, M. V., Matrai, P. A., Leck, C., Rauschenberg, C. D., Lee, A. M., and Coz, E.: Marine microgels as a source of cloud condensation nuclei in the high Arctic, P. Natl. Acad. Sci. USA, 108, 13612-13617, doi:10.1073/pnas.1102457108, 2011.

Pacyna, E. G., Pacyna, J. M., Fudala, J., Strzelecka-Jastrzab, E., Hlawiczka, S., Panasiuk, D., Nitter, S., Pregger, T., Pfeiffer, H., and Friedrich, R.: Current and future emissions of selected heavy metals to the atmosphere from anthropogenic sources in Europe, Atmos. Environ., 41, 8557-8566, doi:10.1016/j.atmosenv.2007.07.040, 2007.

Pacyna, J. M.: Estimation of the Atmospheric Emissions of TraceElements from Anthropogenic Sources in Europe, Atmos. Environ., 18, 41-50, 1984.

Pacyna, J. M. and Pacyna, E. G.: An assessment of global and regional emissions of trace metals to the atmosphere from anthropogenic sources worldwide, Environmental Reviews, 9, 269298, 2001.

Pfeifer, G. D., Harrison, R. M., and Lynam, D. R.: Personal exposures to airborne metals in London taxi drivers and office workers in 1995 and 1996, Sci. Total Environ., 235, 253-260, 1999.

Schepanski, K., Tegen, I., and Macke, A.: Saharan dust transport and deposition towards the tropical northern Atlantic, Atmos. Chem. Phys., 9, 1173-1189, doi:10.5194/acp-9-1173-2009, 2009.

Sholkovitz, E. R., Sedwick, P. N., Church, T. M., Baker, A. R., and Powell, C. F.: Fractional solubility of aerosol iron: Synthesis of a global-scale data set, Geochim. Cosmochim. Ac., 89, 173-189, doi:10.1016/j.gca.2012.04.022, 2012.

Siefert, R. L., Johansen, A. M., and Hoffmann, M. R.: Chemical characterization of ambient aerosol collected during the southwest monsoon and intermonsoon seasons over the Arabian Sea: Labile-Fe(II) and other trace metals, J. Geophys. Res.-Atmos., 104, 3511-3526, doi:10.1029/1998jd100067, 1999.

Spokes, L., Jickells, T., and Jarvis, K.: Atmospheric inputs of trace metals to the northeast Atlantic Ocean: the importance of southeasterly flow, Mar. Chem., 76, 319-330, 2001.

Steinsberger, S. C., Dewees, W. G., Bell, A. C., Finken, R. A., Knoll, J. E., and Midgett, M. R.: Development and Validation of the Us-Epa Hexavalent Chromium Source Emissions Measurement Method, Fuel Process. Technol., 39, 265-276, 1994.

van Pinxteren, D., Bruggemann, E., Gnauk, T., Muller, K., Thiel, C., and Herrmann, H.: A GIS based approach to back trajectory analysis for the source apportionment of aerosol 
constituents and its first application, J. Atmos. Chem., 67, 1-28, doi:10.1007/s10874-011-9199-9, 2010.

Wallace, L. and Slonecker, T.: Ambient air concentrations of fine (PM2.5) manganese in US national parks and in California and Canadian cities: The possible impact of adding MMT to unleaded gasoline, J. Air Waste Manage., 47, 642-652, 1997.

Wang, X. L., Sato, T., Xing, B. S., Tamamura, S., and Tao, S.: Source identification, size distribution and indicator screening of airborne trace metals in Kanazawa, Japan, J. Aerosol Sci., 36, 197-210, doi:10.1016/j.jaerosci.2004.08.005, 2005.

Wedepohl, K. H.: The Composition of the Continental-Crust, Geochim. Cosmochim. Ac., 59, 1217-1232, 1995.

Weisel, C. P., Duce, R. A., Fasching, J. L., and Heaton, R. W.: Estimates of the Transport of Trace-Metals from the Ocean to the Atmosphere, J. Geophys. Res.-Atmos., 89, 1607-1618, 1984.

Weller, R., Woltjen, J., Piel, C., Resenberg, R., Wagenbach, D., Konig-Langlo, G., and Kriews, M.: Seasonal variability of crustal and marine trace elements in the aerosol at Neumayer station, Antarctica, Tellus B, 60, 742-752, doi:10.1111/j.16000889.2008.00372.x, 2008.
Witt, M., Baker, A. R., and Jickells, T. D.: Atmospheric trace metals over the Atlantic and South Indian Oceans: Investigation of metal concentrations and lead isotope ratios in coastal and remote marine aerosols, Atmos. Environ., 40, 5435-5451, doi:10.1016/j.atmosenv.2006.04.041, 2006.

Wolff, G. T., Ruthkosky, M. S., Stroup, D. P., Korsog, P. E., Ferman, M. A., Wendel, G. J., and Stedman, D. H.: Measurements of Sox, Nox and Aerosol Species on Bermuda, Atmos. Environ., 20, 1229-1239, 1986.

Zoller, W. H., Gordon, G. E., Gladney, E. S., and Jones, A. G.: Sources and Distribution of Vanadium in Atmosphere, Adv. Chem. Ser., 31-47, 1973. 